University of Nebraska - Lincoln

DigitalCommons@University of Nebraska - Lincoln

To Improve the Academy

Professional and Organizational Development Network in Higher Education

1997

University Professors at Mid-life: Being a Part of ... But Feeling Apart

Irene E. Karpiak

Follow this and additional works at: https://digitalcommons.unl.edu/podimproveacad

Part of the Higher Education Administration Commons

Karpiak, Irene E., "University Professors at Mid-life: Being a Part of ... But Feeling Apart" (1997). To Improve the Academy. 380.

https://digitalcommons.unl.edu/podimproveacad/380

This Article is brought to you for free and open access by the Professional and Organizational Development Network in Higher Education at DigitalCommons@University of Nebraska - Lincoln. It has been accepted for inclusion in To Improve the Academy by an authorized administrator of DigitalCommons@University of Nebraska - Lincoln. 
Karpiak, I. E. (1997). University professors at mid-life: Being a part of ... but feeling apart. In D. DeZure (Ed.), To Improve the Academy, Vol. 16 (pp. 21-40). Stillwater, OK: New Forums Press and the Professional and Organizational Development Network in Higher Education. Key Words: Faculty Attitudes, Faculty, Organizational Climate.

\section{University Professors at Mid-life: Being a Part of...But Feeling Apart}

\section{Irene E. Karpiak}

The University of Oklahoma

This article explores the experiences of mid-career and older faculty members in higher education through a qualitative study of 20 associate professors (15 men and 5 women) between the ages of 41 and 59 at a Canadian university. In non-directive interviews, "graying" professors discussed their satisfactions and struggles, not only in relation to their students and their academic work, but also in relation to the whole university and its administration. An emergent schema is presented that identifies four attitudes characteristic of this group of professors: Meaning, Malaise, Marginality, and Mattering.

University campuses today are characterized by a graying professoriate. A significant number of professors are finding themselves at later stages of their career, facing the tasks and turbulence of mid-life within institutions themselves struggling to survive in a restless and uncertain world. As this group of professors confronts problems of job fulfillment, quality of teaching, scholarship, and productivity (Boice, 1986; Blackburn \& Lawrence, 1986), their administrators speculate upon the productivity of these middle-aged and older members, often steering the "deadwood" in university departments toward early re- 
tirement or out of academe and into alternative careers. Two assumptions may underlie these administrative responses: first, that older faculty are not as profitable to the university as a younger group of academics would be; and second, that it is "natural" for older professors to disengage from their disciplines, to stagnate, and to turn their attention to non-academic activities. These assumptions and presuppositions about older faculty have contributed to a situation in which little is done to facilitate and support the continued productive efforts and further development of mid-life faculty or to integrate age-related policies and practices into the university.

\section{Purpose of the Study}

This study evolved out of questions concerning the mid-life and mid-career condition of university professors from the perspective of lifespan and adult development. The object of the study was to explore how university faculty experience the mid-career period, a time when most are also in mid-life, and how they live out this period with respect to their academic and community work, their personal and family relationships, and their sense of self. Among the questions asked were:

a) What happens to university faculty's orientation to their discipline, their research, their teaching, and to their collegial relationships during this period of life and career?

b) What sorts of changes and renewals do faculty undergo and undertake?

c) What factors support, impact or impede them?

A qualitative approach to the study was used because it was expected that this approach would permit an "inside" individual view - how individuals perceive, make meaning of, and respond to the circumstances of their professional life during mid-career.

\section{Propositional Inventory}

Two major theoretical perspectives provided the background propositions for this study: the first, adult development theory, emphasizes that development continues throughout life right to the time of death, as does the potential for professional, psychological, and spiritual development. Some researchers regard this period to be "the 
prime of life," rich with possibilities for renewal and psychological growth. Among them, Jung described the second half of life as a time of astonishing change and personal transformation for many individuals, and he stressed the possibilities for individuals at this time to attain greater integration and balance of personality and fulfillment of their potentiality (Jung, 1954). Jung's observation is supported by more recent researchers of lifespan development (Neugarten \& Gutmann, 1968; Levinson et. al., 1978; Fiske \& Chiriboga, 1990). Erikson was among the first theorists to recognize and name the different developmental tasks that adults face. One such task of middle adulthood is to resolve the psychosocial conflict of generativity versus stagnation, where generativity refers to caring and commitment toward the next generation, and where stagnation refers to its opposite-the sense of doubt and malaise concerning one's contribution. This latter tendency toward stagnation has specifically been identified by other researchers of mid-life university faculty (Thoreson, 1984; Cafarella et al., 1989). The question remains: Are malaise and doubt necessary features of this time of life for mid-life faculty or are they responses to the circumstances in which faculty find themselves?

The second area of research deals with the situational context of higher education faculty more generally and with the range of individual, organizational, and environmental factors that contribute to career growth and advancement. Career advancement, change, and faculty vitality are conceived to be the product of interactions among individual characteristics and institutional factors. For example, opportunities for career growth and advancement have been found to influence the amount of effort employees exert and the degree of work commitment they feel (Kanter, 1979). The concept of faculty "vitality" is related both to individual and organizational factors (Clark, Boyer, \& Corcoran, 1985). Among those organizational factors that contribute to faculty success are funds, reduced course loads, public recognition, warm relations, and genuine care. Other studies (Baldwin, 1990) point to the presence of multiple factors, including the important role of administrators in furthering faculty success and renewal. 


\section{Methodology}

This study is based on a sample of 20 associate professors between the ages of 41-59 in the Faculty of Arts at a Canadian research university. Associate professors ( $15 \mathrm{men}$ and 5 women) were the focus because they were both at mid-career and at the mid-level in professorial rank, with the potential for further development and promotion. While no attempt had been made to recruit the sample from a representative group of academic disciplines; as it turned out, individuals from each department were included. Further, while the majority of the participants were faculty members, some individuals were at present, or had been in the past, administrative heads.

Data were collected through personal interviews held on two occasions. All interviews were tape-recorded and then transcribed. Two non-directive interviewing instruments were used. The first was an exercise called "clustering." "Clustering" is an evocative tool in creative writing that has the capability to generate images, ideas, feelings, and recalled experience (Rico, 1983). In this study, it was adapted to be a data gathering tool for research. Accordingly, individuals were led to cluster around the core phrase, "I, myself at mid-career and mid-life." The points or phrases that each person identified around the core phrase then formed the structure of that person's interview. Each person was asked to address each point in the detail and depth to which he or she desired. The second part of the interview consisted of an open-ended interview questionnaire that addressed specific questions, for example: "What, if any, changes have you experienced in the recent past?" "What matters most to you now?" In a second interview, held about one month later, participants were asked to respond to and comment upon the preliminary findings and emergent themes. A more detailed account of the methodology and a description of the major themes generated from the dialogue appear in a previous paper (Karpiak, 1996). 


\section{Analysis of the Data}

It is glory - to have been tested, to have had our little quality and cast our little spell. The thing is to have made somebody care.

-Henry James, The Middle Years, p. 189

Our human need to care, to be cared for and about, that is expressed in the quote above, emerged early in the interviews and remained a consistent theme. This central theme ran through virtually all of the interviews, particularly for those individuals beyond 50 years old. The greatest proportion of their dialogue was devoted to the theme of relationships. Faculty highlighted the centrality of personal and family relationships; but what was striking was the value that they placed on qualities of their relationships within academe and with colleagues: care, support, affirmation, acceptance, acknowledgment, and mutuality. These were uppermost among their concerns. It should be noted that the younger participants (those in their 40's) emphasized different aspects of relationships, primarily those that would support them in their attainment of professional goals. However, for the most part, they were equally articulate in voicing a desire for a more human quality of relationship on the part of the university administrators toward their faculty.

As the interviews progressed and as the above-mentioned themes took shape, one comment made by one study participant stood out. It voiced what was being said by most of this group concerning its desires and its needs. In the midst of discussing her family life, specifically her elderly parents, one woman offered, "Not [that I have] concern for them, but [I have] an interest in their interests, interest in what they're looking for, and forward to in their lives." Captured in this statement was the precise sense of what these study participants were saying about what they wanted from the university. They wanted the administration to be interested in their interests. Hence, "interest in" became the central idea around which the organizing framework for data analysis came to be built.

The concept of interest and its related notion of caring are not new to the literature of mid-life. Erikson (1969) had identified the issue of caring as central to middle adulthood. He states, "in this stage a man and a woman must have defined for themselves what and whom they 
have come to care for, what they care to do well, and how they plan to take care of what they have started and created" $(1969$, p. 395$)$. From this perspective-of interest and caring, I began to analyze the data. I considered these questions: Do these individuals have something that they are interested in and care about? Where and to whom is their interest and caring directed? To what extent are these directed to teaching, research, family and/or community? What has meaning for them? And correspondingly, turning toward the university administration, I asked, to what extent do faculty believe that the university administration is interested in them and caring of what they care about? That is to say, to what extent do faculty believe that what they do and care about matters to the university?

Out of this exercise emerged the following concepts: Meaning, Malaise, Marginality, and Mattering. Meaning and Malaise would characterize what is revealed about the nature and extent of faculty's caring; while Marginality and Mattering would characterize what faculty perceive to be the nature and extent of the university administration's caring. Figure 1, maps out these four concepts and their elucidation in this study.

\section{Meaning} seminars.

If I were to die tomorrow, I would probably come back and teach -Josh age 53

Meaning is represented in the upper right-hand quadrant. "Meaning" refers to the faculty member's high interest and caring with regard to academic responsibilities. This quadrant reflects faculty members' high degree of involvement in and a high quantity of physical and psychological energy devoted to the academic experience that includes tasks, roles, activities, and projects. An assumption is made that the amount of time and energy that an individual devotes to an activity, be it teaching, research, or administration, is a potent indicator of what is meaningful for an individual (Levinson et al., 1978). Accordingly, it would be fair to say that what has meaning and significance for faculty can be discerned from the objects toward which they direct their time and energy. 
Nearly half of the study group could be said to express high Meaning. Jeff, age 53, is a good example. He has been with the University since entering academe. Throughout his career, he has experienced the disappointment of denial of tenure (later granted) and the challenge of being department chair. He expects that, on the basis of his publication output, he will not achieve rank of full professor. On the other hand, he loves to teach; and he expresses similar fondness for his students. He is asked to serve on more doctoral committees than any other member of his department. Also, he is active in the community and in university affairs, including support services to academics. Lately, he has shifted his attention to research related to older adults, and he notes, "I have fun with the old people. I collect data. I love these old people. They challenge you. And they challenge you out of their life experience. I learn a lot in my talks with them."

Echoing this attitude of interest and caring is Paul, age 56, who comments that he keeps having to replace his carpet because of the holes worn through it from the constant student traffic. He estimates that he writes about 100 reference letters each year for students and meets with each one before the letter is written. On the matter of his teaching, he offers, "You've got to be a giver to be successful. I think you've got to be really interested in students. You've got to like people enormously. Because it's not just a question of lecturing; it's a question of relationships. "His enthusiasm extends also to the research he is doing on political affairs, an area that has made him known in the community and internationally. His publications, however, by virtue of their appeal to a more popular audience, have not earned him a promotion.

Individuals in this quadrant are highly invested in what they do academically. For most of them, teaching is a vocation. They engage actively in mentoring, guiding, and watching. They see their students as "a good crop" and "full of hope." Significantly, their teaching appears to undergo an elaboration and enrichment, as, over time, they develop and deepen their style. Among the changes are their inclination to be more relaxed, more flexible, less content driven, less dogmatic, more adventurous, and more willing to express their personal point of view. For some individuals, the teaching prize has been a goal towards which they had worked through conscious reflection 
FIGURE 1

A Schema of Faculty and University Interest and Caring

\section{Madeseo}

Expression: I'm not as good as I could be; I'm not as good as I was." Featureas: Bumout, utvial pursult, need for renewal, thinking of retirement.

Evidence in Reseanch: Low interest in research; Some peaked early; Efforts to publish are frustrated; Stil hoping for "the gold."

Evidence in Teaching: Teaching is stresstul, unrewarding; Low self-estoem, sell-blame, puzded; Blame students' low quality and molvation; See students "On the road o nowhere; Alienation, depersonalizaton; Distressed over age gap with students; Hope/desire for renowal-a surge.

\section{Low mterest}

And Caring

Expression: "Im a ghost"

Marginallty

Features: Feeling "out of things"- on the periphery; Not part of the big picture.

Evidence: Low collegiality, bolated, exctuded; Low investment in the university; Angy, stubbom, frustrabed; Women feel unaccepted, unentitied; Exacerbated by disrupsion in career, or loss of grant funds; Teaching and service are seen as devalued; New theories in field render them a maker of buggy whips"; Made worse If in a small sub-discipline or area of study; Made worse when research is highty specialized; May um to famity and/or external pursults; Waiting to ride that wave again.

\section{Faculty Nember}

Moening

Expression: "..J'd probebly corno back and bach seminars."

Featurea: Define what or who they care about, Satistaction with the academic work; Concern extended bo others.

Evidence in Researctr: High Among Women and younger men; Moderate interest, yet ongoing for older.

Evidence in Teaching: High interest in baching: seen as a vocation;

Mentoring, guiding, watching; See students full of hope, "a good crop"; Despair over distance from students; Try new taaching approaches; Soek out new directions, new areas of study; Find stength in areas of competence; Find meaning regardless of not mattering.

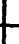
High hinterest And Caning

\section{Mattering}

Expreasion: "The market has tumed against people of our generation." Features: Administration is interested in us and depends on us; The administration is concerned with our fate.

Evidence: The absence of evidence in this quadrant is a primary feature of this study.

Instaad, faculty foel lett out of problem-solving and decision-making; Feol unappreciated, unacknowledged; The human element is missing."; Administrators are "ghosty figures," not visible; It is less of a concem for younger faculty; In crises, visits from administrators are apprectated; The value of a thank you" for work done. 
on their teaching, studying their evaluations, and adjusting their methods.

A smaller number of professors, especially the younger faculty (in their 40's) and most of the women, express their high Meaning through research. For them, it is research that 'beckons." The women, especially, are highly invested in their work and strongly committed to research. Moreover, they express in their research a penchant for venturing through doors that will lead them into ever new areas of research. Several women described how their research was taking them across disciplinary boundaries, further than even they thought they ought go. Put simply, these women are not stuck. One factor that stood out that might shed light on their strong commitment to their work was the irregular career path that most of the women had taken-a switch in professions, later life doctoral study, child-rearing - all had the effect of disrupting their original career or academic path. Jan, age 55, recalled wistfully the day that she, at age 33, retired from a very promising academic career in order to be home with her young children, "This was one of the hardest things I ever did. I remember a retirement party, it was me and a man of 67 ....that was strange." Today, reintegrated into academic life and strongly engaged in research, despite a life-threatening illness, she observes, "I have a kind a energy for [research] now that my own children have grown up and gone, that I don't think I had before. Or I don't think I took it quite that seriously. Now I do." Some literature suggests that the different career trajectories of women, especially their re-engagement with work following a break, may actually contribute to the heightened energy and commitment that women at this age bring to their vocation. This hypothesis found support among the women in this study.

In sum, most of these individuals find high Meaning in teaching; some, especially those younger, as well as most of the women, find high Meaning in research. And, finally, and equally significant, these individuals in high Meaning express the greatest degree of interest and concern for the well-being of their academic colleagues. In other words, these individuals are the ones who extend themselves most, both formally and informally, to their colleagues. 


\section{Malaise}

I'm not as good as I could be, and I'm not as good as I was.

-George age 51

Malaise, in the upper left-hand quadrant, represents faculty members' low interest and caring, which may include a loss of meaning, stagnation, and a sense of triviality and unimportance in what they are doing. Malaise is also closely related to burnout-emotional exhaustion, depersonalization, and reduced personal accomplishments (Farber, 1983).

Symptoms of Malaise - fatigue, exhaustion, low self-esteem, and need for renewal-were noted among the older individuals, primarily the men. To a lesser degree, symptoms of fatigue and exhaustion were noted also among several of the older women. Individuals in Malaise generally have low interest in research (except for one man who tries, but cannot get his work published). The extreme case is Harold, age 54. He has not been productive as a researcher and now finds himself with a large teaching and administrative load with many students. He exhibits a sense of exhaustion, overall tiredness, fatigue, and selfblame. He wonders, "maybe its unfair for me to be here and teach [students] the road to nowhere." Yet further, he observes, "The most important thing to me is I don't just want to go through the motions, I don't want to be here [just] because my salary is higher than it used to be. I can't stay here just for the pay." He is considering early retirement in order to spare the system. In another instance, at age 48, Don's struggle centers on the changes related to post-modernism within his own discipline, changes that have made it more difficult for him to maintain his earlier publication level, leaving him "in this prison house of silence." In his teaching, too, Don reflects a particular face of burnout-alienation and depersonalization. He compares his teaching to performing a Las Vegas act: "You do classes, but every time it's like a performance. You go on stage... The students are satisfied... I've learned to live with it."

Malaise is most evident in teaching because of its decidedly different presentation from that of faculty who describe themselves to be more in line with the "Meaning" quadrant. It is hard to be productive; student absenteeism, lack of student responsiveness, low student 
interest thwart faculty efforts to teach. These faculty perceive the quality of students to be low, the age gap wide, and the overall distance between them and the students to be great. Also distressing to them is their sense of being isolated, alone, and unnoticed. They may look for help through counseling or approaches to their department head, but these do not seem to lead to any resolution. Especially noteworthy is that while the onset and progression of malaise appears to be gradual, its effects intensify.

A most significant feature of this group is that in the midst of Malaise is the presence of hope that things can still turn around. Harold, age 54, mentioned above, bears this out: "I'm looking forward to productive teaching if I can get over this hump right now." And their expectation concerning a change is something that should not be overlooked. Not one of them sees this condition as a permanent state. Erikson (1982) bears out this feature in his description of the lively and dynamic tension that exists between the opposing poles of stagnation (boredom) and generativity (creativity). Our tendency is to move between these. And this leads to a third point: that this dynamic relationship operates in both directions-from Malaise to Meaning and also from Meaning to Malaise. That is to say, individuals in the "Meaning" quadrant could find themselves in "Malaise" (and there were examples to support this), just as those in "Malaise" could be brought back to "Meaning." Each attitude or state of being holds the potential for movement into its opposite.

\section{Marginality}

I am a ghost, you won't find me here very often.

-Joe age 54

Marginality, in the lower left-hand quadrant, represents the faculty member's view of the university as a place of low interest and caring. Marginality refers to the degree to which individuals feel "out of it," distanced from the institution, outside of the mainstream of their sphere-the university, colleagues, students, or even their own discipline.

While some individuals are able to feel enjoyment and meaning in their academic endeavors, others find themselves increasingly 
marginalized from the mainstream of university affairs; they may retain a presence in particular roles, such as teaching or research, but they are rarely present in their offices, and, for the most part, are removed from the day-to-day operations of university life. Absent faculty present a difficult challenge to their colleagues: They frustrate anyone trying to ensure a meeting quorum. Even more distressing, an old message pinned for days on a faculty member's door leaves other colleagues concerned and uneasy, but not knowing quite what to do.

Joe, age 54, illustrates the phenomenon of Marginality. Earlier in his career, he was heavily invested in research and able to secure grants for his very specialized area of research. But governmental priorities changed, funds dried up, and he has been stymied in his efforts to secure funds upon which his research depends. Now disheartened, he wonders, "Who wants someone who's so specialized? It's not like you're working on cancer and are going to solve a problem. Who cares what I'm doing?" He reflects on his own history in his early 40's of being highly motivated and in high Meaning, and being now in his current state, where, "Those days of enthusiasm are gone." He expresses bitterness toward the university for being unsupportive of his predicament. Consequently, while he continues to be available to students, he has all but absented himself from his department. He rarely come into the office, spending most of his time with his students, whom he says he supports and cares about deeply.

Marginality manifests itself in other ways too. As teaching is perceived to be "seriously devalued," those faculty who focus primarily on teaching frequently bemoan their sense of being less acceptable and marginalized. They view their teaching, which takes "huge amounts of time," as "a limiting objective." Among the consequences of the devaluing of teaching is a feeling for some that their own work is devalued. A not surprising consequence is a lessened commitment to the teaching role.

Women consistently express their sense of Marginality within the university and within their own departments. While they, like their male counterparts, mention feeling unacknowledged and unappreciated, women additionally cope with a sense of feeling unaccepted and unentitled. And this sense is not limited to their experience with the administration, but extends to their relationship with departmental 
male colleagues as well. Sandra, age 54, who described a "very anti-female bias" in her male-dominated department, has felt so ignored and dismissed by her colleagues and so alienated from the decision-making that she has quit altogether attending departmental meetings. The image of female faculty as "the novice" and "the impostor" frequently came to mind as these women, even the seasoned academics, related their experiences.

Marginality can extend even to those who are members of a sub-discipline or an area of study with few faculty. These individuals also express feelings of isolation and exclusion from the mainstream. And finally, new theories and new feminist and post-modern perspectives can promote among some faculty a sense of being out of step with the times, or, as one member expressed it, being "a maker of buggy whips."

As may be evident, Marginality can pervade many areas of academic life; notwithstanding, it is most significant that individuals in this quadrant, for the most part, view their present state of affairs as only temporary. Those who feel Marginalized, just as those described earlier who were in Malaise, continue to hold out hope for changes that might reverse their predicament and permit their reentry into the mainstream. They are ready to "wait for the next wave and ride it out," if only something within the university would change.

\section{Mattering}

The market has turned against people of our generation.

-Mike age 54

Mattering, in the lower right-hand quadrant, represents the faculty member's view of the university as high in interest and caring. Mattering refers to the feeling that others depend on us, are interested in us, are concerned with our welfare and our fate. It suggests that we command the notice of others, that others care about what we want, think, and do; that they are proud of our accomplishments or saddened by our failures; and finally, that others depend on us and appreciate us. When we believe we matter to someone, this acts as a motivator for our actions (Rosenberg \& McCullough, 1981). 
Following along the framework, the Mattering quadrant would have contained data concerning faculty's perception that the university is interested in and cares about their interests. The most striking finding of this study, however, is the relative absence of any data of this sort. In other words, there is little evidence to suggest that faculty perceive there to be interest and caring on the part of the university, and, rather, more to suggest its opposite-that faculty feel they do not matter to the university. This sense was particularly apparent among the older faculty members, but not exclusively so.

Not Mattering is expressed through comments in which faculty note the absence of caring, appreciation, acknowledgment, involvement, or support on the part of the administration. Jean, age 59, observes, "The people that (sic) really do have a sense of deep commitment to their discipline, to their profession, are beginning to feel that they are doing all this in a kind of vacuum, and nobody gives a damn." Faculty, in general, find the university to be a cold, isolated, fragmented environment, "a hard place to love," "a wilderness" in which "the human element seems to be missing." Similarly, they describe members of the administration as "invisible" and as "ghostly figures" who avoid setting foot outside their administrative offices and onto departmental turf. Relations between faculty and administration are described as non-collegial, ranging from "distant" and "impersonal" to "war-like" and "adversarial." As Louise, age 46, sums up, "The only way the University seems to, or the administrators, seem to be interested in the way people are developing is in terms of judging them." A most graphic expression of the sense of loss of the "core" within the faculty is expressed below by Joe, age 54 , mentioned earlier, whose metaphor captures his sense of despair over an administration that is overly interested in its external environments and insufficiently concerned with its own faculty:

It seems to me the administration is focused outward [toward the government]. It's like a fort that's being attacked by hostile Indians. And they are so intent on protecting the fort, as they should be; but they can't see that the core is deteriorating. There is no fort to protect anymore. Let them have it. 
While many faculty voiced their concern around not Mattering, not feeling part of a caring community, it was surprising to hear how affected these individuals were by those few instances when they did experience a sense of Mattering: when the President visited them during a personal crisis, when they received teaching awards, or when a "thank you" was offered for work they had done.

The critical importance of Mattering - the feeling that the university cares and does "give a damn"-is powerfully summarized in a study by Blackburn et al. (1991), who described the relationship between the perception of being cared about to the willingness to fulfill one's teaching role:

In summary... if I am genuinely interested in teaching and I believe my institution cares, I will give a lot of time to it; if I am not very interested and/or do not believe my institution cares, I will not give a lot of time to it, all of this irrespective of my gender, where I work, what field I am in, how long I have been an academic, what rank I hold, what my specialty is, whether my department or institution supports teaching, or whether my colleagues care (p. 378).

Blackburn et al. (1991) suggest that even those who have a high interest in teaching can become disheartened when they perceive that what they do does not matter. That is to say, if those in the Meaning quadrant find themselves in an environment of not Mattering, they could fall into a state of Malaise.

\section{A Schema of Faculty Attitudes}

The schema represented in Figure 1 maps out the four central quadrants and the concepts and attitudes emerging from this study. It illuminates several features that may be useful to administrators and faculty developers concerned with the predicament of university faculty at mid-career and mid-life:

- It signals the dynamic nature of the relationship that exists between the individual faculty member and the university environment as well as the complex interplay of behaviors of individual faculty members and administrators, whereby each may be acted upon and, in turn, acts upon. 
- It demonstrates that the perception of the individual concerning his or her environment is an important factor in shaping that individual's behavior. That is, there are qualities in the environment that the individual subjectively defines, interprets, and then responds to.

- It suggests that there is mutual interaction, transaction, and interdependence among the four quadrants of the schema. Just as in a hanging mobile, changes in any quadrant will influence what happens in every other quadrant.

- While individual faculty may appear to represent the qualities or attitudes of any one of the respective quadrants, their place is not a static or permanent one. Individuals can and likely will move from one quadrant to another over the course of a career, a term, or even a day.

One value of this schema lies in the opportunities it affords faculty development personnel as well as administrators to understand the nature of present interactions and influences on faculty and to envision possible future transactions. For instance: What could be the influence of an increase of interest and caring (Mattering) by the university administration on those individuals experiencing burnout or Malaise, or, for that matter, Marginality? What could be the effect of not Mattering on those faculty members who have a high sense of Meaning in work? Further, what could be the benefit to the university of having greater numbers of faculty in high Meaning, given their strong interest in the well-being of their colleagues? Thus, we can begin to appreciate both the painful and the productive aspects of the interactions. It is important also to view these interactions as always in motion, always changing, often on the brink of change. Note that even those who could be described as Marginal or who described themselves that way still viewed this status as one that could change; that they could "once again ride on that wave."

\section{Recommendations}

The study participants offered suggestions that they believed would contribute to improving emotional, and work-related aspects of academic life. The following recommendations were expressed over 
and over again. In the view of this group, the university administration should do the following:

- Provide academic support and resources for research, including space to carry out research, and also time, through lower teaching loads, reduced administrative duties, and mini-sabbaticals;

- Communicate to the public through the media the valuable contributions of faculty and support staff and defend its members more vigorously before the public;

- Promote greater acceptance of women in the departments;

- Acknowledge the particular circumstances of women faculty, e.g., child-bearing, and be flexible about the personal demands on women;

- Put into administrative positions people who are interested in resolving conflict;

- Promote among faculty a sense that they are involved in a joint enterprise, and that they are members of a team;

- Foster an environment in which colleagues stimulate each other's intellectual interests and help each other to develop and grow as intellectuals;

- Develop support networks so that faculty know they are not alone-sponsored networks, informal networks, and services wherein colleagues can offer support to others;

- Help staff fulfill their potential for the last 10 or 15 years of their lives by providing resources, such as career counseling, for people in mid-career;

- "Humanize" the institution through more realistic expectations of faculty and recognition and support of the different efforts and contributions that they bring, e.g., teaching.

The recommendations offered by faculty members have implications for faculty developers, particularly those responsible for fostering intellectual growth among faculty, developing support networks, providing career counseling for faculty, and "humanizing" the institution. At the very least, they point to a broadening of faculty developers' roles. One aspect of this wider role might include more integrative activity, that is, bringing the needs of faculty to the awareness of administrators. The second might suggest more coordinating activity, that is, bringing the interests, concerns, and aspirations of 
faculty members closer to their colleagues. And finally, and perhaps, most challenging, is an interpretive activity that would permit faculty developers to deepen their understanding of individual faculty members through experiencing them as individuals with feelings and attitudes that call out to be appreciated and understood.

\section{Conclusion}

We have to face that fact that we are middle-aged and, like the chimney sweepers, will come to dust.

-Gary age 48

Above, Gary voices an awareness that appears to distinguish this group of faculty from their younger counterparts - their awareness of death that often emerges with mid-life. This and other features-the importance of relationship, communion, and community that this group of faculty have expressed-suggest that mid-life faculty members represent a unique and special population, different from their younger counterparts with respect to their needs, aspirations, motivations, and vulnerabilities. To the extent that the university acknowledges and responds to the needs of older faculty, they will likely continue to make a contribution in those areas they care about.

An attitude of caring and concern is reflected in the participants' comments and recommendations, not only for themselves, but also for other colleagues. Their desire is evident to create a more humane environment in which faculty can feel that they are dealt with fairly and that they matter to others. And, underlying these is an apparent assumption that contented, high Meaning faculty will be more productive, more alive, and more able to contribute to the community of teachers, students, and colleagues. The findings suggest that this "high Meaning" group, above all, needs to be nurtured and supported because they are also the ones who extend themselves most to colleagues, students, and the community. Those in Malaise similarly need support. They are not content to be in their state and are struggling to move out of it. And finally, each of the above-mentioned recommendations supports the necessity of attending to the Mattering quadrant and filling the void that currently exists in this institution and perhaps in others as well. 
The solutions do not appear to lie in accommodating to the shortcomings and failings of the faculty, just as it does not lie in ignoring the agenda and preoccupation of the administration. Rather, it would seem to lie in the willingness of both to participate in the mutual creation of a humane work environment in which both stand not in "war" and opposition, but side by side in the direction of individual and institutional goals. But to do that, both groups will need to give up the presuppositions, fixed ideas, and certainties about what an effective faculty member looks like or does and what an effective administrator looks like and does.

Through my meetings with these individuals, I have heard a high degree of concern for their students, regard for their colleagues, and sadness over reduced opportunities to interact with both. I heard their humanness. That is what they shared with me, and for that I am deeply grateful. If I can serve them now it would be to communicate their humanness in a way that might touch readers as it touched me. Like, Jeff, I too wish to believe:

When you get a group saying what we're saying, the world will never be the same again.

-Jeff age 53

\section{References}

Baldwin, R. G. (1990). Faculty vitality beyond the research university. Journal of Higher Education, 61(2), 160-180.

Blackburn, R. T., \& Lawrence, J. H. (1986). Aging and the quality of faculty job performance. Review of Educational Research, 23, 265-290.

Blackburn R. T., Lawrence, J. H., Bieber, J. P., \& Trautvetter, L. (1991). Faculty at work: Focus on teaching. Research in Higher Education, 32, 363-381.

Boice, R. (1986). Faculty development via field programs for middle-aged, disillusioned faculty. Research in Higher Education, 25, 115-35.

Cafarella, R. S., Armour, R. A., Fuhmann, B. S., \& Wergin, J. F. (1989). Mid-Career faculty: Refocusing the perspective. The Review of Higher Education, 12, 403-410.

Clark, S. M., Boyer, C., \& Corcoran, M. (1985). Faculty and institutional vitality in higher education. In S. M. Clark \& D. R. Lewis (Eds), Faculty vitality and institutional productivity (pp. 3-24). New York: Teachers College Press.

Erikson, E. H. (1982). The life cycle completed. New York: W. W. Norton \& Company.

Erikson, E. H. (1969). Ghandi 's truth. Magnolia, MA: Peter Smith Publisher. 
Farber, B. A. (1983). A critical perspective on burnout. In B. A. Farber (Ed.), Stress and burnout in the human service professions. New York: Pergamon Press.

Fiske, M., \& Chiriboga, D. (1990). Change and continuity in adult life. San Francisco: Jossey-Bass.

James, H. (1992). The middle years. In J. C. Oates (Ed.), The Oxford book of American short stories (pp. 170-169). Oxford, OH: Oxford University Press.

Jung, C. G. (1954). The development of personality. Collected works, the development of personality. Princeton, NJ: Princeton University Press.

Kanter, R. M. (1979). Changing the shape of work: Reform in academe. Current Issues in Higher Education, 1, 3-9.

Karpiak, I. E. (1996). Ohosts in a wilderness: The problems and priorities of faculty at mid-career and mid-life. Canadian Journal of Higher Education, XXVI-3.

Levinson, D. J., with Darrow, C. N., Klein, E. B., Levinson, M. H., \& McKee, B. (1978). Seasons of a man's life. New York: Ballantine Books.

Neugarten, B. L., \& Gutmann, D. (1968). Sociological perspectives of the life cycle. In P. B. Baltes, \& K. W. Schaie (Eds.), Life-span developmental psychology: personality and socialization. New York: Academic Press.

Rico, G. L. (1983). Writing the natural way. Los Angeles: J. P. Tarcher.

Rosenberg, M., \& McCullough, B. C. (1981). Mattering: Inferred significance and mental health among adolescents. Research in Community Mental Health, 2, 163-182.

Thoreson, R. W. (1984). The professor at risk: Alcohol abuse in academe. Journal of Higher Education, 55, 56-72.

\section{Contact:}

Irene E. Karpiak

Educational Leadership \& Policy Studies

The University of Oklahoma

Norman, 73019-0260 USA

(405) 3254202

(405) 3252403

Ilkarpiak@ou.edu

Irene E. Karpiak is professor of adult and higher education in the Department of Educational Leadership and Policy Studies at The University of Oklahoma. Her areas of research include adult and mid-life learning and development and program development for adult and continuing higher education. 